\title{
STRATEGI TWO STAY TWO STRAY DALAM PEMBELAJARAN APRESIASI CERPEN
}

\author{
Syamsuddin \\ Sekolah Tinggi Ilmu Keperawatan Gunung Sari \\ Jalan Sultan Alauddin 293 Makassar, Sulawesi Selatan \\ Email: samsuddin@yahoo.co.id
}

\begin{abstract}
The Two Stay Two Stray Strategies in Learning Short Story Appreciation. This study aimed to describe the ability to appreciate the effectiveness of the two stay two stray strategy in the learning of short stories appreciation of class X High School Students of Gunung Sari Makassar. The study was designed with artificial experiments. Sampling in this study used total sampling technique. The instruments used, namely observation and tests. The collected data were analyzed using descriptive statistical analysis techniques and inferential statistical t-test types are processed through the program SPSSX 19. The results demonstrate the ability of students to appreciate the stories with two types of cooperative learning strategies categorized stay two stray high and (2) two types of cooperative learning strategies stay two stray effectively applied in teaching appreciation of short stories.
\end{abstract}

\begin{abstract}
Abstrak: Keefektifan Strategi Two Stay Two Stray dalam Pembelajaran Apresiasi Cerpen. Penelitian ini bertujuan mendeskripsikan kemampuan mengapresiasi cerpen dan keefektifan strategi tipe two stay two stray dalam pembelajaran apresiasi cerpen siswa kelas X SMA Gunung Sari Makassar. Penarikan sampel dalam penelitian menggunakan teknik total sampling. Instrumen yang digunakan, yaitu pedoman observasi dan tes. Data yang terkumpul dianalisis dengan menggunakan teknik analisis statistik deskriptif dan statistik inferensial jenis uji t yang diolah melalui program SPSSX 19. Hasil penelitian menunjukkan kemampuan siswa mengapresiasi cerpen dengan strategi pembelajaran kooperatif tipe two stay two stray dikategorikan tinggi dan strategi pembelajaran kooperatif tipe two stay two stray efektif diterapkan dalam pembelajaran apresiasi cerpen.
\end{abstract}

Kata kunci: pembelajaran sastra, strategi pembelajaran, two stay two stray

Salah satu spesifikasi materi pembelajaran apresiasi sastra di SMA adalah apresiasi cerita pendek (cerpen). Apresiasi cerpen adalah kegiatan menggauli karya sastra secara sungguhsungguh sehingga menumbuhkan pengertian, penghargaan, kepekaan pikiran kritis, dan kepekaan perasaan yang baik terhadap karya sastra. Berdasarkan pendapat itu, disimpulkan bahwa kegiatan apresiasi dapat tumbuh dengan baik apabila pembaca mampu menumbuhkan rasa akrab dengan karya sastra yang diapresiasinya, menumbuhkan sikap sungguh-sungguh, serta melaksanakan kegiatan apresiasi itu sebagai bagian dari hidupnya, sebagai suatu kebutuhan yang mampu memuaskan rohaninya (Aminuddin, 2004).
Dalam ruang lingkup pembelajaran bahasa Indonesia di SMA Gunung Sari Makassar terdapat indikasi adanya fluktuasi daya serap siswa pada aspek pengapresiasi cerpen. Demikian halnya dengan tingkat ketuntasan materi pelajaran. Pada sisi yang lain, terdapat pula kenyataan bahwa siswa kurang termotivasi belajar cerpen, khususnya bidang apresiasi karena siswa merasa pembelajaran cerpen kurang bermanfaat dalam hubungannya dengan kehidupan kesehariannya dan dengan kehidupan siswa pada masa mendatang. Fenomena tersebut diketahui berdasarkan hasil pengamatan selama ini dan survei pembelajaran bahasa Indonesia di sekolah.

Masalah yang timbul dalam proses belajar mengajar, khususnya dalam pembelajaran cer- 
pen, sebagaimana uraian tersebut disebabkan oleh kurangnya hubungan komunikatif antara guru dan siswa, serta siswa dengan siswa lainnya sehingga proses interaksi menjadi vakum. Padahal, proses belajar mengajar dipengaruhi oleh perilaku saling interaksi dan penuh dengan kooperatif (Ibrahim, 2000). Oleh karena itu, untuk menciptakan suasana pembelajaran apresiasi cerpen yang kooperatif dan interaktif, guru harus cermat memilih dan menerapkan strategi pembelajaran, seperti strategi kooperatif.

Slavin (dalam Sanjaya, 2007), menyatakan dua alasan dianjurkannya pembelajaran kooperatif, yakni pertama, beberapa hasil penelitian menunjukkan bahwa penggunaan pembelajaran kooperatif dapat meningkatkan prestasi belajar siswa sekaligus juga dapat meningkatkan hubungan sosial, menumbuhkan sikap menerima kekurangan diri dan orang lain, serta dapat meningkatkan harga diri. Kedua, pembelajaran kooperatif dapat merealisasikan kebutuhan siswa dalam belajar berpikir, memecahkan masalah, dan mengintegrasikan pengetahuan dengan keterampilan.

Belajar kooperatif tidak semata-mata mengharapkan siswa dapat bekerja sama dalam pembelajaran. Lebih dari itu, melalui strategi ini, para siswa diharapkan dapat saling mengenal menghargai perbedaan-perbedaan yang ada melalui interaksi yang dibentuk dalam pembelajaran di kelas. Lie (2002:12) menyamakan belajar kooperatif dengan sistem pembelajaran gotongroyong. Sistem pembelajaran gotong-royong yang dimaksud adalah sistem pembelajaran yang memberi kesempatan kepada siswa untuk bekerja sama dalam menyelesaikan tugas-tugas yang terstruktur. Lebih jauh, Lie (2002:3) menyebutkan lima unsur pembelajaran gotong-royong yang ditetapkan dalam pembelajaran kooperatif, yakni (1) saling ketergantungan positif, (2) tanggung jawab perseorangan, (3) tatap muka, (4) komunikasi antar-anggota, dan (5) evaluasi proses kelompok.

Pembelajaran kooperatif merupakan model pembelajaran dengan menggunakan sistem pengelompokan/tim kecil, yaitu antara empat sampai enam orang yang mempunyai latar belakang kemampuan akademik, jenis kelamin, ras, atau suku yang berbeda (heterogen). Sistem penilaian dilakukan terhadap kelompok. Setiap kelompok akan memeroleh penghargaan (reward), jika kelompok mampu menunjukkan prestasi yang dipersyaratkan (Sanjaya, 2007:12).
Salah satu aplikasi pembelajaran kooperatif adalah tipe two stay two stray "Dua yang tinggal di kelompoknya dan dua yang bertamu ke kelompok lain". Strategi belajar kooperatif tipe tipe two stay two stray" dua tinggal dua adalah suatu strategi yang melibatkan lebih banyak siswa dalam menelaah materi yang tercakup dalam suatu pelajaran dan mengecek pemahaman mereka terhadap isi pelajaran. Strategi ini menghendaki siswa saling bekerja sama dan berbagi pendapat dalam sebuah kelompok kecil.

Segala isu pembelajaran bahasa Indonesia, khususnya apresiasi cerpen selama ini diasumsikan dapat diselesaikan jika guru mengacu pada strategi pembelajaran kooperatif tersebut, yakni tipe two stay two stray "dua yang tinggal di kelompoknya dan dua yang bertamu ke kelompok lain". Alasannya, tipe two stay two stray "dua yang tinggal di kelompoknya dan dua yang bertamu ke kelompok lain" pada dasarnya adalah strategi belajar yang mengutamakan kerja sama antara individu dengan kelompok dengan saling berbagi pendapat di antara sekian banyak kelompok. Dengan demikian, tidak ada siswa yang belajar sendiri-sendiri. Siswa bermasyarakat dengan siswa lain sehingga ketika siswa tidak mengetahui suatu masalah, ia dapat dibantu oleh siswa yang sudah tahu.

Kompetensi dasar apresiasi cerpen dijadikan sebagai materi pembelajaran dalam penelitian ini karena apresiasi cerpen salah satu keterampilan dalam pembelajaran bahasa Indonesia yang sulit dikuasai oleh siswa. Padahal, materi itu merupakan salah satu materi inti dalam pembelajaran bahasa dan sastra Indonesia. Oleh karena itu, melalui penerapan tipe two stay two stray "dua yang tinggal di kelompoknya dan dua yang bertamu ke kelompok lain" diharapkan segala problematika yang selama ini menghambat peningkatan hasil belajar bahasa Indonesia, khususnya apresiasi cerpen dapat diatasi.

Penelitian strategi tipe two stay two stray "dua yang tinggal di kelompoknya dan dua yang bertamu ke kelompok lain" tersebut dilakukan dengan asumsi bahwa penelitian yang relevan, terutama dalam pembelajaran apresiasi cerpen kurang diperhatikan. Penelitian sebelumnya hanya mengkaji tipe Think Pair Share (TPS) dalam pembelajaran apresiasi cerpen (Saidah, 2009). Saidah meneliti tentang keefektifan pembelajaran kooperatif model Think Pair Share (TPS) dalam meningkatkan apresiasi cerpen siswa kelas XI SMA Negeri 1 Sinjai Timur, Kabupaten Sin- 
jai. Hasil penelitiannya menunjukkan bahwa tipe Think Pair Share (TPS) efektif diterapkan dalam meningkatkan kemampuan mengapresiasi cerpen siswa kelas XI SMA Negeri 1 Sinjai Timur, Kabupaten Sinjai.

Penelitian yang dilakukan Saidah (2009) memiliki persamaan dengan penelitian ini, yakni mengkaji pembelajaran apresiasi cerpen. Namun, lebih banyak perbedaan terutama pada aspek subjek dan lokasi penelitian. Selain itu, berbeda strategi yang digunakan, yaitu antara strategi Think Pair Share (TPS) dan strategi two stay two stray. Oleh karena itu, penelitian ini dilakukan untuk memperkaya penelitian tentang pembelajaran apresiasi cerpen dengan menggunakan strategi tipe two stay two stray. Penelitian ini bertujuan mendeskripsikan kemampuan mengapresiasi cerpen siswa kelas X SMA Gunung Sari Makassar dengan menerapkan strategi tipe two stay two stray dan mendeskripsikan keefektifan strategi tipe two stay two stray dalam pembelajaran apresiasi cerpen siswa kelas $\mathrm{X}$ SMA Gunung Sari Makassar.

\section{METODE}

Desain penelitian yang digunakan dalam penelitian ini adalah desain penelitian eksprimen. Penelitian ini merupakan penelitian eksperimen yang terdiri atas dua kelompok, yaitu kelompok eksperimen (kelompok yang menerapkan strategi tipe two stay two stray dalam pembelajaran apre-siasi cerpen) dan kelompok kontrol (kelompok yang tidak menerapkan strategi tipe two stay two stray dalam pembelajaran apresiasi cerpen).

Penelitian ini dilaksanakan di kelas $\mathrm{X}$ SMA Gunung Sari Makassar tahun pelajaran 2010/2011. Pelaksanaan dilaksanakan selama 4 bulan, yakni Januari sampai dengan April tahun 2011. Populasi penelitian ini adalah keseluruhan siswa kelas X SMA Gunung Sari Makassar yang berjumlah 50 orang yang terbagi ke dalam tiga kelas. Sifat dan karakteristik populasi penelitian ini adalah homogen karena penempatan siswa dalam suatu kelas tidak didasarkan pada tingkat prestasi belajar. Penarikan sampel dalam penelitian ini menggunakan teknik total sampling.

Untuk memeroleh data penelitian ini digunakan instrumen. Instrumen yang digunakan, yaitu pedoman observasi dan tes. Jadi, teknik yang digunakan untuk mengumpulkan data penelitian ini adalah teknik observasi dan tes. Observasi dilakukan guna memeroleh gambaran dan kondisi awal pembelajaran mengapresiasi cerpen. Sementara, teknik tes, yaitu tes apresiasi cerpen. Dalam pelaksanaannya, siswa ditugasi mengapresiasi cerpen dengan kompetensi dasar dalam KTSP kelas X semester satu. Data yang terkumpul dalam penelitian dianalisis dengan menggunakan teknik statis-tik inferensial jenis uji t.

\section{HASIL DAN PEMBAHASAN}

\section{Kemampuan Siswa Kelas X SMA Gunung Sari Makassar Mengapresiasi Cerpen}

Berdasarkan hasil analisis data dengan 25 orang siswa, tidak ada siswa yang mampu memeroleh nilai 100 sebagai nilai maksimal. Nilai tertinggi yang dicapai oleh siswa adalah 90 yang dicapai oleh 4 orang (16\%) dan nilai terendah yang diperoleh oleh siswa adalah 76,6 yang dicapai oleh 3 siswa (12\%). Selanjutnya, sampel yang mendapat nilai 86,7 berjumlah 2 orang (8\%); sampel yang mendapat nilai 83,3 berjumlah 8 orang (32\%); sampel yang mendapat nilai 80 berjumlah 7 orang (28\%); sampel yang mendapat nilai 76,7 berjumlah 1 orang (4\%).

Tabel 1. Distribusi Nilai Kemampuan Mengapresiasi Cerpen dengan Strategi Tipe Two Stay Two Stray Kelas Eksperimen

\begin{tabular}{lrr}
\hline & \multicolumn{1}{c}{ Kelas } \\
Eksperimen
\end{tabular}

Berdasarkan hasil analisis deskriptif tersebut diperoleh rangkuman nilai kemampuan mengapresiasi cerpen siswa kelas X SMA Gunung Sari Makassar dengan menerapkan strategi tipe two stay two stray pada berbagai karakte- 
ristik distribusi nilai. Untuk lebih jelasnya, rangkuman karakteristik distribusi nilai yang diperoleh siswa ditunjukkan pada tabel 1 .

Berdasarkan kategori kemampuan tersebut dapat dinyatakan bahwa tidak ada siswa yang memeroleh nilai pada kategori kemampuan sangat tinggi $(0 \%)$. Selanjutnya, sampel yang memeroleh nilai pada kategori kemampuan tinggi sebanyak 25 orang (100\%); tidak ada sampel yang memeroleh nilai pada kategori kemampuan sedang, rendah, dan sangat rendah. Hal ini menunjukkan bahwa tingkat kemampuan mengapresiasi cerpen siswa dengan menerapkan strategi tipe Two Stay Two Stray dikategorikan tinggi.

Nilai siswa tersebut dapat dikonversikan ke dalam klasifikasi ketuntasan kemampuan mengapresiasi cerpen dengan menerapkan strategi tipe two stay two stray, yaitu sampel yang memeroleh nilai 70 ke atas berjumlah 25 siswa (100\%) dan tidak ada siswa sampel yang memeroleh nilai di bawah $70(0 \%)$. Dengan demikian, dapat dikatakan bahwa keriteria ketuntasan kemampuan mengapresiasi cerpen dengan menerapkan strategi tipe two stay two stray kelas eksperimen memadai. Hal ini dibuktikan dari nilai yang diperoleh siswa sampel yang memeroleh nilai 70 ke atas mencapai kriteria tingkat kemampuan siswa sampel, yaitu $85 \%$.

\section{Nilai Kelas Kontrol}

Berdasarkan hasil analisis data sebanyak 25 orang siswa yang dianalisis diperoleh gambaran, yaitu tidak ada siswa yang mampu memeroleh nilai 100 sebagai nilai maksimal. Nilai tertinggi yang dicapai oleh siswa adalah 53,3 yang dicapai oleh 3 orang (12\%) dan nilai terendah yang diperoleh siswa adalah 17,5 yang dicapai oleh 1 siswa (4\%).

Selanjutnya, sampel yang mendapat nilai 50 berjumlah 3 orang (12\%); sampel yang mendapat nilai 47,6 berjumlah 3 orang (12\%); sampel yang mendapat nilai 43,3 berjumlah 3 orang (12\%); sampel yang mendapat nilai 60 berjumlah 6 orang (24\%); sampel yang mendapat nilai 37,6 berjumlah 1 orang (4\%); sampel yang mendapat nilai 36,6 berjumlah 2 orang (8\%); sampel yang mendapat nilai 33.3 berjumlah 1 orang (4\%); sampel yang mendapat nilai 30 berjumlah 1 orang (4\%); sampel yang mendapat nilai 23,3 berjumlah 1 orang (4\%).
Berdasarkan hasil analisis deskriptif tersebut diperoleh rangkuman nilai kemampuan mengapresiasi cerpen siswa tanpa menerapkan strategi tipe two stay two stray pada berbagai karakteristik distribusi nilai. Untuk lebih jelasnya, rangkuman karakteristik distribusi nilai yang diperoleh siswa ditunjukkan pada tabel 2 .

Tabel 2. Distribusi Nilai Kemampuan Mengapresiasi Cerpen dengan Strategi Two Stay Two Stray Kelas Kontrol

\begin{tabular}{lrr}
\hline & & \multicolumn{2}{c}{ Kelas } \\
& Kontrol \\
\hline $\mathrm{N}$ & Valid & 25 \\
& Missing & 0 \\
Mean & & 41.5000 \\
Std. Error of Mean & 1.79781 \\
Median & 40.0000 \\
Std. Deviation & 8.98907 \\
Variance & 80.803 \\
Range & 35.80 \\
Minimum & 17.50 \\
Maximum & 53.30 \\
\hline
\end{tabular}

Berdasarkan tabel 2, dapat diketahui bahwa di antara 25 siswa yang dites, nilai tertinggi yang diperoleh siswa adalah 53,30. Selanjutnya, nilai terendah yang diperoleh siswa adalah 17,50; nilai rata-rata adalah 41,50 ; median adalah 40; standar deviasi adalah 8,98.

Berdasarkan kategori kemampuan yang ditetapkan dapat dinyatakan bahwa tidak ada siswa yang memeroleh nilai pada kategori kemampuan sangat tinggi, tinggi, dan sedang $(0 \%)$. Selanjutnya, sampel yang memeroleh nilai pada kategori kemampuan rendah sebanyak 3 orang (12\%); sampel yang memeroleh nilai pada kategori kemampuan sangat rendah sebanyak 22 orang $(88 \%)$. Hal ini menunjukkan bahwa tingkat kemampuan mengapresiasi cerpen siswa tanpa menerapkan strategi tipe two stay two stray dikategorikan sangat rendah.

Nilai siswa tersebut dapat dikonversikan ke dalam klasifikasi ketuntasan kemampuan mengapresiasi cerpen siswa tanpa menerapkan strategi tipe two stay two stray, yaitu tidak ada sampel $(0 \%)$ yang memeroleh nilai $70 \mathrm{ke}$ atas, sedangkan siswa sampel yang memeroleh nilai di bawah 70 berjumlah 25 siswa (100\%). Dengan demikian, dapat dikatakan bahwa ketuntasan kemampuan mengapresiasi cerpen tanpa 
Tabel 3. Hasil Uji Paired Samples Test

\begin{tabular}{|c|c|c|c|c|c|c|c|c|c|}
\hline & & \multicolumn{5}{|c|}{ Paired Differences } & \multirow{2}{*}{$\begin{array}{c}\mathrm{t} \\
\text { Mean } \\
\end{array}$} & df & $\begin{array}{l}\text { Sig. (2- } \\
\text { tailed) }\end{array}$ \\
\hline & & Mean & $\begin{array}{c}\text { Std. } \\
\text { Deviation }\end{array}$ & $\begin{array}{c}\text { Std. } \\
\text { Error } \\
\text { Mean } \\
\end{array}$ & $\begin{array}{r}95 \% \text { Confide } \\
\text { of the Di }\end{array}$ & $\begin{array}{l}\text { e Interval } \\
\text { rence }\end{array}$ & & $\begin{array}{c}\text { Std. } \\
\text { Deviation }\end{array}$ & $\begin{array}{c}\text { Std. } \\
\text { Error } \\
\text { Mean } \\
\end{array}$ \\
\hline & & Lower & Upper & Lower & Upper & Lower & Upper & Lower & Upper \\
\hline $\begin{array}{l}\text { Pair } \\
1\end{array}$ & $\begin{array}{l}\text { Kelas } \\
\text { Eksperimen - } \\
\text { Kelas Kontrol }\end{array}$ & 41.15200 & 10.00380 & 2.00076 & 37.02264 & 45.28136 & 20.568 & 24 & .000 \\
\hline
\end{tabular}

menerapkan strategi tipe two stay two stray kelas kontrol belum memadai. Hal ini dibuktikan dari nilai yang diperoleh sisa sampel yang memeroleh nilai 70 ke atas tidak mencapai kriteria tingkat kemampuan siswa sampel, yaitu $85 \%$. Perolehan nilai siswa tersebut tidak mencapai ketuntasan yang ditetapkan, yakni $85 \%$ siswa yang harus mendapat nilai $70 \mathrm{ke}$ atas.

\section{Keefektifan Strategi Two Stray Two Stay dalam Pembelajaran Cerpen}

Keefektifan strategi tipe two stay two stray dalam pembelajaran apresiasi cerpen siswa kelas X SMA Gunung Sari Makassar tersebut diukur berdasarkan perolehan nilai kelas eksperimen dan kelas kontrol. Selanjutnya, berdasarkan perolehan nilai kelas eksperimen dan kelas kontrol dilakukan analisis statistik deskriptif uji t Paired Samples Test.

Berdasarkan hasil analisis data, maka diperoleh bahwa nilai t 20,568 dengan signifikansi (p) 0,000. Kaidah pengujian hipotesis digunakan apabila $p>0,05$. Kesimpulan adalah bahwa hipotesis diterima, sehingga ada perbedaan yang signifikan antara kelas yang menggunakan strategi pembelajaran kooperatif tipe two stay two stray dengan tanpa menggunakan strategi pembelajaran kooperatif tipe two stay two stray. Dengan demikian, strategi pembelajaran kooperatif tipe two stay two stray "dua yang tinggal di kelompoknya dan dua yang bertamu ke kelompok lain" efektif diterapkan dalam pembelajaran apresiasi cerpen.

\section{PEMBAHASAN}

Pembahasan hasil penelitian ini mencakup kemampuan siswa dan keefektifan strategi pembelajaran two stay two stray.

\section{Kemampuan Mengapresiasi Cerpen dengan Strategi Two Stay Two Stray}

Dalam pembelajaran apresiasi cerpen bagi kelas yang tidak menerapkan strategi tipe two stay two stray, yaitu siswa mengalami kendala dan hambatan. Rata-rata siswa mengalami kebingungan, hanya tinggal diam, dan kurang bersemangat dalam belajar. Mereka sulit memahami cerpen karena guru hanya menugasi siswa secara per orangan, tidak terjadi interaksi dan kerja sama antara siswa.

Segala masalah pribadi yang dihadapi oleh siswa dalam belajar sulit diselesaikan karena tidak adanya diskusi dan curah gagasan (brainstorming) dengan siswa lain sebagai sarana penyelesaian masalah belajar. Selain itu, terkadang ada unsur-unsur cerpen sulit dimaknai oleh siswa, seperti menentukan tema, amanat, latar, penokohan, sudut pandang, gaya bahasa, dan bahkan unsur yang berkaitan dengan nilai sosial, agama, pendidikan, dan sebagainya.

Aktivitas dan kegiatan siswa pada siswa yang tidak menerapkan strategi tipe two stay two stray menunjukkan bahwa semangat dan perhatian siswa dalam pembelajaran masih kurang. Hal ini tampak dari kurangnya perhatian serius dari siswa dalam menanggapi materi. Sikap siswa pada umumnya masih kurang dalam memberikan tanggapan terhadap metode yang disajikan.

Pada saat pembelajaran berlangsung, hanya sebagian kecil siswa yang benar-benar aktif. Selain itu, ditemukan adanya siswa yang melakukan aktivitas yang tidak ada hubungannya dengan pelajaran seperti berbincang-bincang dengan sesama teman dan mengerjakan tugas pelajaran yang lain. Masih ada siswa yang melakukan aktivitas yang tidak ada hubungannya dengan pelajaran tidak mengambil peranan dalam kelas sehingga pada saat diskusi dan per- 
sentase berlangsung hanya sebagian kecil yang aktif. Hal ini menunjukkan bahwa siswa kurang memiliki motivasu dan ketertarikan untuk belajar.

Berdasarkan hasil pengamatan penulis ditemukan hal yang berpengaruh pada rendahnya kemampuan siswa mengapresiasi cerpen, yaitu (1) pemahaman siswa terhadap apresiasi cerpen masih kurang; (2) struktur dan variasi kelas kurang variatif; (3) guru kurang mengarahkan siswa dalam belajar; (4) siswa malas menyelesaikan tugas; (5) banyak siswa yang melakukan kegiatan lain saat belajar; (6) siswa tidak berani mengerjakan tugas dan tidak bertanya jika ada masalah yang dihadapi.

Fenomena yang dialami oleh siswa dalam mengapresiasi cerpen tersebut berdampak pada evaluasi hasil belajar. Dapat diketahui bahwa frekuensi dan persentase kemampuan siswa mengapresiasi cerpen, yaitu tidak siswa (0\%) yang mendapat nilai 70 ke atas. Berdasarkan data tersebut, dapat dinyatakan bahwa kemampuan mengapresiasi cerpen siswa kelas kontrol (tanpa menerapkan strategi tipe two stay two stray) belum memadai. Bukti lain yang menunjukkan rendahnya kemampuan mengapresiasi cerpen, yaitu perolehan nilai rata-rata yang rendah, yaitu 41,50.

Berbeda dengan fenomena yang terjadi dalam pembelajaran apresiasi cerpen siswa dengan menerapkan strategi pembelajaran kooperatif tipe two stay two stray "dua yang tinggal di kelompoknya dan dua yang bertamu ke kelompok lain". Tampak semua siswa seolah tidak mengalami kendala dalam menjawab permasalahan. Siswa mampu memahami dan mengapresiasi dengan baik cerpen. Menurutnya, mudah memahami dan menilai cerpen karena selain guru yang menjadi tempat bertanya dan diskusi, siswa lain pun bisa dijadikan sebagai sumber penyelesaian masalah. Masalah yang timbul atau yang diajukan oleh guru diselesaikan secara bersama. Jika ada siswa yang kurang memahami, maka siswa lain dapat membantu sehingga terjadi tutor sebaya dalam pembelajaran. Segala masalah pribadi siswa dalam belajar diselesaikan secara bersama melalui kegiatan curah gagasan (brainstorming).

Hal tersebut berdampak positif pada nilai yang diperoleh siswa dalam mengapresiasi cerpen. Dapat dinyatakan bahwa tingkat kemampuan mengapresiasi cerpen siswa dengan menerapkan strategi tipe two stay two stray dikatego- rikan tinggi. Demikian halnya dengan ketuntasan belajar rata-rata mencapai kriteria ketuntasan kemampuan mengapresiasi cerpen. Hal ini dibuktikan dari nilai yang diperoleh siswa sampel yang memeroleh nilai 70 ke atas mencapai kriteria tingkat kemampuan siswa sampel, yaitu $85 \%$.

Masalah yang terjadi pada kelas kontrol yang berpengaruh pada rendahnya kemampuan siswa mengapresiasi cerpen sebagaimana dipaparkan sebelumnya dapat diselesaikan dengan menerapkan strategi two stay two stray. Masalah yang dimaksud, seperti (1) pemahaman siswa terhadap apresiasi cerpen rata-rata bagus; (2) struktur dan variasi kelas yang variatif dan menyenangkan bagi siswa; (3) guru mengarahkan siswa dalam belajar; (4) siswa proaktif dalam menyelesaikan tugas; (5) rata-rata siswa memfokuskan perhatian pada materi pembelajaran; (6) keberanian dan kepercayaan diri siswa dalam mengerjakan tugas, dan masalah diselesaikan secara kooperatif dengan sistem diskusi kelompok.

Hasil pembelajaran mengapresiasi cerpen siswa kelas kontrol dan eksperimen tampak jelas berdasarkan perbandingan dalam tabel 4 berikut.

Tabel 4. Perbandingan Hasil Pembelajaran Kelas Kontrol dan Kelas Eksprimen

\begin{tabular}{lcc}
\hline \multicolumn{1}{c}{$\begin{array}{c}\text { Aspek yang } \\
\text { dibandingkan }\end{array}$} & $\begin{array}{c}\text { Kelas } \\
\text { Kontrol }\end{array}$ & $\begin{array}{c}\text { Kelas } \\
\text { Eksprimen }\end{array}$ \\
\hline $\begin{array}{l}\text { Mean (nilai } \\
\text { rata-rata) }\end{array}$ & 41.50 & 82.65 \\
$\begin{array}{l}\text { Nilai terendah } \\
\text { Minimum }\end{array}$ & 17.50 & 76.60 \\
$\begin{array}{l}\text { Maximum } \\
\text { Ketuntasan } \\
\text { dengan nilai } 70\end{array}$ & 53.30 & 90.00 \\
ke atas & $0 \%$ & $100 \%$ \\
\hline
\end{tabular}

\section{Keefektifan Strategi Tipe Two Stay Two Stray} dalam Pembelajaran Apresiasi Cerpen

Slavin (1995:13) menyatakan bahwa pembelajaran kooperatif, khususnya tipe two stay two stray"dua yang tinggal di kelompoknya dan dua yang bertamu ke kelompok lain" diajarkan keterampilan-keterampilan khusus agar dapat bekerja sama dengan baik di dalam kelompoknya, seperti menjadi pendengar yang baik, siswa diberi lembar kegiatan yang berisi pertanyaan atau tugas yang direncanakan untuk diajarkan. 
Selama kerja kelompok, tugas anggota kelompok adalah mencapai ketuntasan. Peran pembelajaran kooperatif tipe two stay two stray "dua yang tinggal di kelompoknya dan dua yang bertamu ke kelompok lain" dalam pembelajaran, khususnya apresiasi cerpen sejalan dengan temuan penelitian ini.

Berdasarkan hasil analisis data, tes kemampuan mengapresiasi cerpen dapat disimpulkan bahwa strategi pembelajaran kooperatif tipe two stay two stray "dua yang tinggal di kelompoknya dan dua yang bertamu ke kelompok lain" cocok digunakan. Hal ini dinyatakan berdasarkan hasil penelitian yang menunjukkan bahwa kemampuan siswa mengapresiasi cerpen meningkat. Pernyataan tersebut didukung dan diperkuat berdasarkan hasil perhitungan tes. Perbandingan hasil kemampuan kelas kontrol dan eksperimen menunjukkan bahwa nilai $t_{\text {hitung }}>$ nilai t tabel. Hal ini menunjukkan bahwa hipotesis penelitian yang diajukan diterima.

Strategi pembelajaran kooperatif tipe two stay two stray "dua yang tinggal di kelompoknya dan dua yang bertamu ke kelompok lain" membantu anak menyelesaikan masalah belajar yang dihadapi. Hal ini dinyatakan karena semua permasalahan pembelajaran dilakukan dengan kerja bersama. Lebih menarik dan menyenangkan bagi siswa saat pembelajaran berlangsung. Saat itu, siswa berkunjung ke kelompok lain mencari informasi dari kelompok lain sesuai dengan masalah yang dipelajari dalam kelompoknya.

Fenomena lain yang tampak, yaitu strategi belajar ini dapat membentuk kepribadian anak dalam menjalin hubungan sosial dengan orang lain (siswa). Melalui strategi ini, selain membantu anak menyelesaikan masalah dalam pembelajaran, secara tidak langsung pun mengajak anak agar mampu bersosialisasi dengan lingkungan sekitarnya kini dan masa yang akan datang. Hal inilah yang perlu ditumbuhkembangkan dalam pembelajaran bahasa Indonesia selain ilmu pengetahuan (kognitif).

Kegiatan pembelajaran yang meningkatkan kemampuan siswa mengapresiasi cerpen dilakukan seperti berikut ini. (1) Guru membentuk kelompok kooperatif tipe two stay two stray; (2) guru memotivasi siswa dengan mengemukakan tujuan dan tema pembelajaran, yakni apresiasi cerpen melalui metode kooperatif tipe two stay two stray; (3) guru menjelaskan kepada siswa tentang langkah-langkah apresiasi cerpen melalui metode kooperatif tipe two stay two stray; (4) guru menjelaskan teori cerpen dan apresiasi cerpen; (5) siswa dalam kelompok membahas teori cerpen dan apresiasi cerpen; (6) secara bergiliran setiap kelompok mengirim utusan sebanyak dua orang untuk berkunjung ke kelompok lain mencari informasi tentang materi yang didiskusikan dan dua orang tinggal di kelompoknya menerima tamu dan bertugas menyampaikan informasi kepada tamu (dua orang) yang datang ke kelompoknya. Setelah berkunjung, siswa kembali ke kelompoknya masing-masing untuk sharing dan berbagi informasi kepada anggotanya; dan (7) guru membimbing siswa menyimpulkan pembelajaran.

Hasil penilaian siswa terhadap cerpen, misalnya penentuan sikap pemerintah yang tergambar sesuai dengan kutipan cerpen berikut ini.

\begin{abstract}
"Aku ingin berkata tidak kepada negara, karena pencarian keadilan tak boleh menjadi sebuah teater, tetapi mutlak hanya pencarian keadilan yang kalau perlu dingin dan beku. Tetapi negara terus juga mendesak dengan berbagai cara upaya tugas itu akan terima. Di situ aku mulai berpikir. Tak mungkin semua itu tanpa alasan. Lalu aku melakukan investigasi yang mendalam dan kutemukan faktanya.
\end{abstract}

Kutipan cerpen tersebut dijadikan sebagai soal dan siswa rata-rata mampu memberkan penilaian yang maksimal. Menurut siswa berdasarkan data kutipan tersebut bahwa sikap pemerintah sesuai dengan kutipan cerpen tersebut adalah tidak sabar dan licik. Hal ini tampak pada tindakannya yang selalu mendesak dalam pengambilan keputusan dan pencarian keadilan di negeri ini. Sesuai dengan kutipan tersebut pemerintah menjalankan keadilan dalam wujud pendesakan dengan berbagai cara upaya. Hal ini mengindikasikan bahwa sikap pemerintah dalam mengambil keputusan sesuai dengan cerpen Peradilan Rakyat tidak berdasar pada fakta dan kebenaran, tetapi berdasar pada keinginannya.

Evaluasi lain yang diberikan siswa adalah tentang nilai dalam cerpen seperti tampak pada kutipan berikut ini.

Ya aku menerimanya, sebab aku seorang profesional. Sebagai seorang pengacara aku tidak bisa menolak siapa pun orangnya yang meminta agar aku melaksanakan kewajibanku sebagai pembela. Sebagai 
pembela, aku mengabdi kepada mereka yang membutuhkan keahlianku untuk membantu pengadilan menjalankan proses peradilan sehingga tercapai keputusan yang seadiladilnya.

Berdasarkan hasil analisis pekerjaan siswa (hasil tes), rata-rata mampu dijawab dengan benar. Sesuai dengan kutipan tersebut, nilai yang dominan adalah nilai moral. Seorang pengacara yang menunjukkan sikap perhatiannya kepada semua orang yang berhak untuk dibantu tanpa memandang status dan golongannya. Nilai moral ini rata-rata dijawab oleh siswa dengan benar.

Peran pembelajaran kooperatif tipe two stay two stray "Dua yang tinggal di kelompoknya dan dua yang bertamu ke kelompok lain" dalam pembelajaran apresiasi cerpen merupakan temuan baru dan menjadi teori yang dapat dijadikan landasan bagi guru bahasa Indonesia untuk meningkatkan hasil belajar siswa. Hal ini dapat dijadikan sebagai metode alternatif bagi guru dalam meningkatkan daya apresiastif siswa terhadap cerpen sebab metode ini mendidik dan menanamkan jiwa kerja sama dan sosial dalam diri siswa.

Berdasarkan uraian tersebut dapat disimpulkan bahwa strategi pembelajaran kooperatif tipe two stay two stray "dua yang tinggal di kelompoknya dan dua yang bertamu ke kelompok lain" efektif digunakan. Hal ini dinyatakan berdasarkan hasil penelitian yang menunjukkan bahwa kemampuan siswa mengapresiasi cerpen meningkat. Pernyataan tersebut didukung dan diperkuat berdasarkan hasil perhitungan tes. Perbandingan hasil kemampuan pretes dan postes menunjukkan bahwa nilai $\mathrm{t}$ hitung $>$ nilai $\mathrm{t}$ tabel. Hal ini menunjukkan bahwa hipotesis penelitian yang diajukan diterima.

Peran pembelajaran kooperatif tipe two stay two stray "dua yang tinggal di kelompoknya dan dua yang bertamu ke kelompok lain" dalam pembelajaran, khususnya apresiasi cerpen sejalan dengan teori yang dikemukakan sebelumnya, yakni Slavin (1995:13) yang menyatakan bahwa pada pembelajaran kooperatif, khususnya tipe strategi pembelajaran kooperatif tipe two stay two stray "dua yang tinggal di kelompoknya dan dua yang bertamu ke kelompok lain" diajarkan keterampilan-keterampilan khusus agar dapat bekerja sama dengan baik di dalam kelompoknya, seperti menjadi pendengar yang baik, siswa diberi lembar kegiatan yang berisi pertanyaan a- tau tugas yang direncanakan untuk diajarkan. Selama kerja kelompok, tugas anggota kelompok adalah mencapai ketuntasan.

\section{PENUTUP}

Berdasarkan hasil analisis data ditemukan bahwa hasil pembelajaran apresiasi cerpen siswa dengan menerapkan strategi pembelajaran kooperatif tipe two stay two stray "dua yang tinggal di kelompoknya dan dua yang bertamu ke kelompok lain" dikategorikan tinggi dan telah mencapai ketuntasan belajar. Hal ini dinyatakan karena nilai yang diperoleh siswa mencapai kriteria yang ditetapkan, yaitu mencapai $100 \%$ atau sebanyak 25 siswa yang mendapat nilai 70 ke atas. Hal tersebut bermakna bahwa strategi two stay two stray "dua yang tinggal di kelompoknya dan dua yang bertamu ke kelompok lain" efektif dalam meningkatkan pembelajaran apresiasi cerpen siswa.

Berbeda dengan pencapaian tersebut, hasil pembelajaran apresiasi cerpen siswa tanpa menerapkan strategi pembelajaran kooperatif tipe two stay two stray "dua yang tinggal di kelompoknya dan dua yang bertamu ke kelompok lain" dikategorikan sangat rendah dan belum mencapai ketuntasan belajar karena nilai yang diperoleh siswa belum mencapai kriteria yang ditetapkan, yaitu tidak ada $(0 \%)$ yang memeroleh nilai $70 \mathrm{ke}$ atas .

Strategi pembelajaran kooperatif tipe two stay two stray "dua yang tinggal di kelompoknya dan dua yang bertamu ke kelompok lain" efektif diterapkan dalam pembelajaran apresiasi cerpen. Perbandingan hasil kemampuan kelas eksperimen dan kelas kontrol menunjukkan bahwa nilai $\mathrm{t}_{\text {hitung }}>$ nilai $\mathrm{t}$ tabel. Hal ini menunjukkan bahwa hipotesis penelitian yang diajukan diterima.

Berdasarkan hasil penelitian, guru bahasa Indonesia disarankan menggunakan strategi ini dalam pembelajaran menulis cerpen. Strategi two stay two stray dapat meningkatkan kerja sama dan motivasi siswa karena mereka memiliki kesempatan untuk berdiskusi dan berbagi dengan sesama dalam satu kleompok. Siswa memiliki kesempatan mengembangkan aspek afektif melalui relasi yang terbangun antar sesamanya. Kesempatan berbagi yang dimiliki juga dapat menumbuhkan kepercayaan diri siswa. Strategi ini juga layak diujicobakan pada aspek pembelajaran sastra lainnya. 


\section{DAFTAR PUSTAKA}

Aminuddin. 2004. Pengantar Apresiasi Karya Sastra. Bandung: Sinar Baru.

Saidah. 2009. "Efektivitas Pembelajaran Kooperatif Model Think Pair Share (TPS) dalam Meningkatkan Apresiasi Cerpen Siswa Kelas XI SMA Negeri 1 Sinjai Timur, Kabupaten Sinjai”. Skripsi. Makassar: FBS UNM.
Sanjaya, Wina. 2007. Strategi Pembelajaran Berorientasi Standar Proses Pendidikan. Jakarta: Kencana.

Slavin, Robert E., 2009. Cooperative Learning. Bandung: Nusa Media. 